九州大学学術情報リポジトリ

Kyushu University Institutional Repository

\title{
Technical Efficiency Among Rice Farmers in Philippine Rice Bowl
}

Fukui, Sei ichi

Seminar of Econometric Analysis in Agriculture, Fuculty of Agriculture, Kyushu University

https://doi.org/10.5109/24021

出版情報：九州大学大学院農学研究院紀要. 37 (3/4)，pp. 289-295，1993-03. Kyushu University バージョン：

権利関係 : 


\title{
Technical Efficiency Among Rice Farmers in Philippine Rice Bowl
}

\author{
Seiichi Fukui \\ Seminar of Econometric Analysis in Agriculture, Fuculty of Agriculture, \\ Kyushu University 46-07, Fukuoka 812, Japan
}

(Received November 27, 1992)

\begin{abstract}
To estimate the technical efficiency among rice farmers and it's contribution to profitability of new rice technology, the frontier production function approach is applied to the data collected in rural Philippines. A statistical test to test whether the functional form is Cobb-Douglas or Translog, suggests that the model can not be better represented by Translog production frontier. The estimation results show that technical efficiency estimated by Cobb-Douglas model contributes around $70 \%$ of the explained profit variability.
\end{abstract}

\section{INTRODUCTION}

In the last two decades, rice farmers in Asian developing countries have adopted modern rice technology. The rapid diffusion of modern technology and improvement of rice variety, however, enlarged the gap of profitability between farmers (Fukui, 1986, Otsuka, 1991).

Although a great deal of effort has been made on the cause of this discrepancy, opinions vary as to the importance of some factors (such as production inefficiency).

As Shapiro and Muller (1977) pointed out, the differences of profitability arise from the different productivity caused by the following reasons; 1) different technologies, 2) random disturbances or 3) different inefficiencies.

The inefficiency can be decomposed into two components: technical inefficiency and allocative inefficiency (Farrell, 1957).

This paper focuses only on technical efficiency and examines the effect of technical efficiency on the level of profit. For that purpose, we identify the sources of the profitability in Philippine rice production, in terms of technical efficiency, resource base and other factors.

To estimate the technical efficiency, we use the frontier production function approach, although this approach has such a theoretical limitation that it does not take account of farm specific prices. This is because the effects of farm specific prices on profit are expected not to play an important role in our study area as shown below in Table 4. In the following sections, first, we estimate Cobb-Douglas and Translog stochastic frontier production function, and test whether the functional form of production frontier is Cobb-Douglas or Translog. Second, the technical efficiency of individual form is computed, using the Cobb-Douglas frontier production function. Finally, we estimate the effect of technical efficiency on profitability of rice production. 
The results show that there is still substantial room for enhancing profitability of modern rice technology by better use of existing technology.

\section{DATA AND METHODOLOGY}

In order to collect micro data of farm economy, we conducted the field survey between June and August 1991, in Muñoz, Mueva Echija Province. We sampled and interviewed with 142 farm households in three rice-growing villages.

The study area is located approximately $200 \mathrm{~km}$ north of Metro Manila, Inner Central Luzon that saw the newly development of huge estates (hacienda), (Hayami and Kikuchi, 1982).

In 1972, Presidential Decree No. 27 under Martial Law was proclaimed and the large haciendas in Central Luzon have been broken down. The land owned by absentee landlords has been transferred to the tenants or the land rent has been reduced to lower level.

Abreast of the land reform, irrigation development, and application of new rice varieties and fertilizers have been executed. Consequently, the rice yields per ha have been increasing from 60 cavans $(1$ cavan $=50 \mathrm{~kg}$ ) in mid 1970's to more than 100 cavans in 1990 (Table 1).

The land reform and the new rice technology brought a significant improvement of profitability to rice farmers (Umehara, 1978, Shimizu and Fukui, 1993).

Despite a remarkable increase of profit, however, profit gap between farmers are still large. Since there is not significant difference of adopted technology in the study area, the profit gap arises from random disturbances and farmer's production inefficiencies.

In this paper, we focus on the technical inefficiency.

For the purpose of estimating the technical efficiency, we use the concept of frontier production function (Forsund, Love11 et al . 1980). The measures of technical

Table 1. Rice Yield in the Study Area.

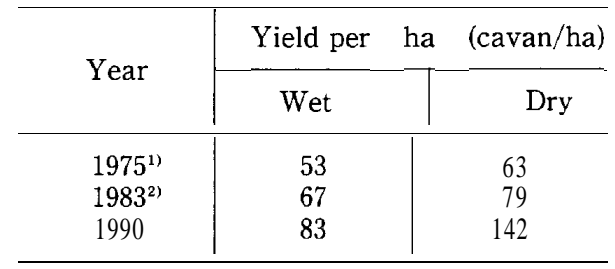

Note: 1) Coloma, P. S., “A Benchmark Study Report: Barrio Bantug, Munoz. N. E., "CLSU, Management Information Center, Research Department. 1977.

2) Bernardo, T. S., and Mangalindan, M. B., "Transaction and Arrangements in Agrarian Reform (Nueva Ecija), " Rural Development Studies, Research and Development Center, CLSU, 1984. 
inefficiency can be derived from estimation of deterministic non-parametric frontier production function (Farrel and Fielhouse, 1962), deterministic parametric frontier production function (Aigner and Chu, 1968), statistical frontier production function (Afriat, 1972, Richmond, 1974) or stochastic frontier production function (Aigner et al., 1977).

Among those, the first three frontiers are deterministic. As Forsund et al. point out, the notion of a deterministic frontier shared by all farmers ignores the real possibility that a farmer's performance may be affected by factors entirely outside its control such as bad weather etc. as well as by factors under its contrail (P. 13). Therefore, we use the stochastic frontier production function approach because rice production is subject to random disturbances.

\section{EMPIRICAL MODEL AND ESTIMATION RESULTS}

The stochastic frontier production function is defined as follows:

$$
\mathrm{Y}_{\mathrm{t}}=\mathrm{F}(\mathrm{X}, \boldsymbol{\beta}) \cdot \mathrm{e}^{\varepsilon_{\mathrm{t}}}(\mathrm{t}=1 \cdots \cdots \cdot \cdots)
$$

where $Y_{t}$ is the annual gross product of rice of $t$-th rice farmer, $X_{t}$ is a vector of inputs such as land, labor, fixed capital and variable capital, $\beta$ is a vector of parameters, $\boldsymbol{\varepsilon}_{\mathrm{t}}$ is composed of two independent error components; $\varepsilon_{t}=V_{t}-U_{t}$ where $V_{t}$ captures the effects of random shocks outside the farmer's control, observation, measurement error on dependent variable, and other statistical noise, $U_{t}$ captures the technical efficiency $\left(\mathrm{V}_{\mathrm{t}} \sim \mathrm{N}\left(\mathrm{O}, \mathrm{a},{ }^{\prime \prime}\right), \mathrm{U}_{\mathrm{t}} \sim \mathrm{N}\left(\mathrm{O}, \mathrm{a},{ }^{\prime \prime}\right), \mathrm{O} \leqq \mathrm{U}_{\mathrm{t}}\right.$.

Here, the technical efficiency of t-th individual producer is defined as

$$
\mathrm{e}^{-\mathrm{ut}}=\frac{\mathrm{Y}_{\mathrm{t}}}{\mathrm{F}\left(\mathrm{X}_{\mathrm{t}}, \beta\right) \cdot \mathrm{e}^{-\mathrm{vt}}}
$$

The conditional mean of $U_{t}$ is shown to be

$$
\mathrm{E}\left(\mathrm{U}_{\mathrm{t}} \mid \varepsilon_{\mathrm{t}}\right)=\sigma^{*}\left[\frac{\mathrm{f}^{*}\left(\varepsilon_{\mathrm{t}} \lambda / \sigma\right)}{1-\mathrm{F}^{*}\left(\varepsilon_{\mathrm{t}} \cdot \lambda / \sigma\right)}-\left(\frac{\varepsilon_{\mathrm{t}} \cdot \lambda}{\sigma}\right)\right]
$$

where $\mathrm{f}^{*}$ and $\mathrm{F}^{*}$ represent the standard normal density and distribution function, respectively, and $\sigma^{* 2}=\sigma_{\mathrm{u}}{ }^{2} \sigma_{\mathrm{v}}{ }^{2} / \sigma^{2}, \sigma^{2}=\sigma_{\mathrm{u}}{ }^{2} \sigma_{\mathrm{v}}{ }^{2}, \lambda={\sigma_{\mathrm{u}}}^{2}{\sigma_{\mathrm{v}}}^{2}$

The estimates of variances used to solve equation (2) are derived from Maximum Likelihood Estimation (MLE) of equation (1).

As for the functional form, we estimate two types of functions, Cobb-Douglas and Translog.

The Translog stochastic frontier production function model can be specified in the loglinear form as follows:

$$
\begin{aligned}
\operatorname{LnY}_{\mathrm{t}}=\beta_{0} & +\Sigma \beta_{1}\left(\operatorname{LnX}_{\mathrm{it}}\right)+\Sigma \beta_{11}\left(\operatorname{LnX}_{\mathrm{it}}\right)^{2} \\
& +\Sigma_{1} \Sigma_{\mathrm{j}} \beta_{\mathrm{ij}}\left(\operatorname{LnX}_{\mathrm{it}}\right)\left(\operatorname{LnX}_{\mathrm{jt}}\right)+\varepsilon_{\mathrm{t}}
\end{aligned}
$$

$\mathrm{X}_{\mathrm{it}}$ or $Z_{\mathrm{ji}}$ is $\mathrm{j}$-th input on the $\mathrm{t}$-th farm.

For the Cobb-Douglas production function ,the coefficients of all interaction terms (i.e. $\beta_{11}, \beta_{1 j}$ ) in equation (3) should be zero.

These two types of stochastic frontier functions are estimated for 142 rice farms, 
using MLE.

The results of estimation are shown in Table 2.

Next we carry out a likelihood ratio test to select the functional form of the production frontier.

The test is conducted to test the null hypothesis that all $\beta_{i 1}=0$ and all $\beta_{1 j}=\mathrm{O}$. If $\mathrm{L}_{1}$ is the value of the Log of likelihood function for the unconstrained Translog model and $\mathrm{L}_{0}$ is the value of Cobb-Douglas model with the constraints, then the likelihood ratio test is conducted, by computing

$$
\mathrm{LR}=2\left(\mathrm{~L}_{1}-\mathrm{L}_{0}\right)
$$

The LR statistic is distributed asymptotically as a chi-squared variance with degrees of freedom equal to the number of constraints.

The computed LR equals 17.34 , while the critical chi-square $\mathrm{X}^{2}(10)$ at $5 \%$ level or $1 \%$ level is $18.31,28.19$ respectively. Therefore, the sample and the model being analyzed are not better represented by Translog rather than Cobb-Douglas production frontier, as shown in Table 2. This results differ with Bagi[1982].

By using the estimated Cobb-Douglas function, we compute technical efficiency of individual farmer to estimate the effect of technical efficiency on the profit of rice production.

The profit of rice production, however, depends on the farm resource base and the other factors as well as technical efficiency. The difference of soil conditions and

Table 2. Estimation Results of Stochastic Frontier Production Function.

\begin{tabular}{|c|c|c|c|c|}
\hline \multirow{2}{*}{ Variables } & \multicolumn{2}{|c|}{ Cobb-Douglas } & \multicolumn{2}{|c|}{ Translog } \\
\hline & Estimate & T-statistic & Estimate & T-statistic \\
\hline Constant & 5.15 & $6.99 *$ & -35.14 & -1.03 \\
\hline Ln (Land) & 0.32 & $3.27 *$ & -8.43 & -1.05 \\
\hline Ln (Labor) & -0.03 & -0.49 & -0.80 & -0.23 \\
\hline Ln (Fixed Capital) & 0.49 & $8.41 *$ & 4.90 & 1.48 \\
\hline Ln (Variable Capital) & 0.20 & $2.70^{*}$ & 6.10 & 0.93 \\
\hline$\{\operatorname{Ln}(\operatorname{Land})\}^{2}$ & & & -0.49 & -1.01 \\
\hline$\{\mathrm{Ln}(\mathrm{Labor})\}^{2}$ & & & -0.11 & -0.89 \\
\hline$\left\{\right.$ Ln $(\text { Fixed Capital }\}^{2}$ & & & 0.13 & 0.59 \\
\hline$\{$ Ln (Variable Capital) $\}$ & & & 0.13 & 0.34 \\
\hline Ln (Land) * Ln (Labor) & & & $0.82 \mathrm{E}-01$ & 0.19 \\
\hline $\operatorname{Ln}($ Land $) * \operatorname{Ln}($ Fixed Capital $)$ & & & 0.45 & 1.06 \\
\hline Ln(Land)* Ln(Variable Capital) & & & 0.58 & 0.72 \\
\hline Ln(Labor)* Ln(Fixed Capital) & & & 0.31 & 1.03 \\
\hline Ln(Labor)* Ln(Variable Capital) & & & $-0.93 \mathrm{E}-01$ & -0.25 \\
\hline Ln(Fixed Capital) * Ln(Variable Capital) & & & -0.96 & $-2.34 *$ \\
\hline Sigma & 2.86 & $39.29 *$ & 3.13 & $38.27^{*}$ \\
\hline Lambda & 3.45 & $3.73 *$ & 3.45 & $3.46 *$ \\
\hline Log of Likehood Function & \multicolumn{2}{|c|}{11.11} & \multicolumn{2}{|c|}{19.79} \\
\hline Likelihood Ratio & \multicolumn{2}{|c|}{ Computed LR $=17.34$} & \multicolumn{2}{|c|}{ 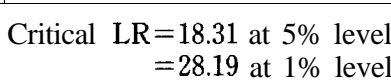 } \\
\hline
\end{tabular}

\footnotetext{
*indicates significance at $1 \%$ level; ** at $5 \%$ level.
} 
Table 3. List of Variables for Estimation.

\begin{tabular}{|c|c|c|}
\hline Name of Variables & Description & Unit \\
\hline Permanent Labor & If farmer use permanent labor. $=1$; Otherwise $=0$ & \\
\hline Family Size & Number of household menber & Person \\
\hline Female Labor Ratio & Ratio of female laborers to family laborers & \\
\hline Family Labor & Number of family laborers & Person \\
\hline Age & Ln $\left\{60-(\text { Age of household head }\}^{2}\right.$ & Year \\
\hline School & Total school year of household head & Year \\
\hline Remittance & Ln (Remittance from family members living apart) & Peso \\
\hline Agricultural Machine & $\begin{array}{l}\text { Ln (Owned Tractor, Thresher and Pump per Planted } \\
\text { Area) }\end{array}$ & Peso \\
\hline Machine \& Animal & Ln (Owned machine, water buffalo and cow) & Peso \\
\hline Rice Price & Ln (Average price of rice traded) & Peso \\
\hline Planted Area & Total area planted of paddy field in one year & Hector \\
\hline Tractor Rental P & Ln (Rental price of tractor for rice production) & Peso \\
\hline Fertilizer Price & $\begin{array}{l}\text { Ln (Normalized price of fertilizer computed as total ferti- } \\
\text { lizer expenditure) }\end{array}$ & Peso $/ 50 \mathrm{~kg}$ \\
\hline $\begin{array}{l}\text { Debt } \\
\text { Technical Efficiency }\end{array}$ & $\begin{array}{l}\mathrm{Ln}(\text { Current outstanding debt) } \\
\mathrm{e}^{-\mathrm{E}(\mathrm{u})}: \mathrm{E}(\mathrm{U}) \text { is the expected value of farm specific ineffi- } \\
\text { ciency } \mathrm{U}\end{array}$ & Peso \\
\hline Profit & $\begin{array}{l}\text { Ln (Annual gross revenue from rice production minus } \\
\text { total sum of fixed capital cost'), variable capital } \text { cost }^{2)} \text {, } \\
\text { labor cost }{ }^{3)} \text { and land rent } t^{4)}\end{array}$ & Peso \\
\hline
\end{tabular}

Note: 1) The sum of flow costs of tractor, thresher, pump and draft animal.

2) Total costs of chemical fertilizer, other chemical inputs and seeds.

3) The sum of labor costs, including all the payments for hired laborers and imputed family labor costs.

4) The imputed land rent, in case of owned land, the actual land rent in case of rented land.

Table 4. Profitability and Technical Efficiency.

\begin{tabular}{|c|c|c|}
\hline \multirow{2}{*}{ Variable } & \multicolumn{2}{|c|}{ Dependent Variable: Profit } \\
\hline & (I) & $(2)$ \\
\hline $\begin{array}{l}\text { Permanent Labor } \\
\text { Family Size } \\
\text { Female Labor Ratio } \\
\text { Family Labor } \\
\text { Age } \\
\text { School } \\
\text { Remittance } \\
\text { Agricultural Machine } \\
\text { Machine \& Animal } \\
\text { Rice Price } \\
\text { Planted Area } \\
\text { Tractor Rental P } \\
\text { Fertilizer Price } \\
\text { Debt } \\
\text { Technical Efficiency }\end{array}$ & $\begin{array}{c}-0.49(-1.29) \\
-0.04(-0.42) \\
-0.95(-1.34) \\
0.23(1.36) \\
0.02(0.27) \\
0.04(0.94) \\
-0.05(-1.25) \\
0.04(0.96) \\
0.01(0.25) \\
1.92(1.34) \\
0.64\left(2.78^{*}\right) \\
-0.02(-0.45) \\
0.05(0.24) \\
0.37(1.17) \\
27.94\left(9.69^{*}\right)\end{array}$ & $\begin{array}{c}-0.55(-1.10) \\
-0.02(-0.22) \\
-1.72\left(-1.85^{* *}\right) \\
0.23(1.05) \\
0.02(0.21) \\
0.07(1.24) \\
-0.03(-0.57) \\
-0.01(-0.18) \\
0.02(0.46) \\
3.43\left(1.84^{*} *\right) \\
0.69\left(2.26^{* *}\right) \\
-0.04(-0.58) \\
-0.02(-0.07) \\
0.04(0.99)\end{array}$ \\
\hline $\mathrm{R}^{2}$ & 0.52 & 0.16 \\
\hline No. of Samples & \multicolumn{2}{|c|}{142} \\
\hline
\end{tabular}

Note: Figures in parentheses refer to t-statistic.

*indicates significance at $1 \%$ level; **at $5 \%$ level. 
irrigation conditions are trivial in the study area. In this paper,we regress the following variables on the profit; 1) the endowment of family labor (family labor, female labor force rate), 2) human capital (educational background, age), 3) fixed capital (machine, animal), 4) land, 5) debt, 6) rice price and factor prices, and 7) technical efficiency. Detailed explanations of each variable are shown in Table 3.

The estimates in Table 4 show that planted area and technical efficiency affect the profitability, positively and significantly. Particularly, the technical efficiency contributed $69 \%$ to the explained profit variability. This implied the importance of technical efficiency in bearing profit.

\section{CONCLUDING REMARKS}

The previous studies of production inefficiencies showed that the differences of productivity (Otsuka) or the inefficiencies (Barker and Herdt) did not seem to be strongly associated with any socioeconomic constraint.

In the study area, however, there are some significant degree of difference in productivity and profitability between farmers. The analysis of this paper shows that the more effective use of existing technology still leave substantial room for improving the profitability of modern rice technology. Since there is fairly general agreement that the improvement of modern variety and the diffusion of new technology have slown down, there seems to be only a small opportunity to raise the level of productivity potential in most locations. One implication of the analysis is that agricultural development policy might better concentrate on the diffusion of existing technology (extension) rather than promoting further technical progress, because there is convincing evidence that extension effects can have a significant effect on output (Birkhaeuser et al., 1991).

\section{REFERENCES}

Afriat, S. N. 1972 Efficiency estimation of production functions. International Econ. Rev. 13: 568 $-598$.

Aigner, D. J. and S. F. Chu 1968 On estimating the industry production function.Amer.Econ. Rev. 58: $826-839$.

Aigner, D. J., C. A. Knox Lovel and P. Schmidt 1977 Formulation and estimation of stochastic frontier function models. $J$. Econometrics. 6: 21-37.

Ah, M. and J. C. Flinn 1989 Profit efficiency among Basmati rice producers in Pakistan Punjab. Amer. J.Agr.Econ. '71: 303-310.

Bagi, F. S. 1982 Economic efficiency of share cropping: reply and some further results. Malayan Econ. Rev. 27: 86-95.

Baker, R. and R. W. Herdt 1985 The Rice Economy of Asia. Resource for the Future (Washington, $\mathrm{DC})$.

Birkhaeuser, D., R. E. Evenson and G. Feder 1991 The economic impact of agricultural extension: A Review. Econ. Develop. and Cultur.Change.39: 607-650.

Farrel, M. J. 1957 The measurement of productive efficiency. J. Royal Statist. Soc. Series A (general). 21: 253-281.

Farrel, M. J. and M. Fieldhouse 1962 Estimating efficient production under increasing returns to scale. J. Royal Statist. Soc. A 125, part 2: 252-267. 
Forsund, F. R., C. A. Knox Lovell and P. Schmidt 1980 A survey of frontier production functions and of their relationship to efficiency measurement. $J$. Econometrics. 13: 5-24.

Fukui, S. 1986 Nougyo no kindaika to tochihoyuu. In "Chuubu Thai Inasaku Nouson no Keizaihenyou" Tokyo Daigaku Touyou Bunka Kenkyusho Houkoku (Tokyo): pp. 93-115 (in Japanese).

Hayami, Y. and M. Kikuchi 1982 Asian Village Economy at the Crossroads.. Johns Hopkins University Press (Baltimore).

Otsuka, K. 1991 Rural Poverty and Access to Land in Asian Rice Economy. The Economic Review. 42: 319-329.

Richmond, J. 1974 Estimating the efficiency of production. International Econ. Rev. 15: 515-521.

Shapiro, K. H. and J. Muller 1977 Sources of technical efficiency: the role of modernization and information. Econ. Develop. and Cultur. Change. 25: 239-310.

Shimizu, H. and S. Fukui 1983 Marcos Nouchikaikaku to Beisaku Hacienda Barrio no Henbou: Sonnai Shougyou Elite no Keisei o Megutte. Shakaikagaku Ronshu (Kyushu Daigaku Kyouyou -bu), (in Japanese).

Umehara, H. 1992 Filippin no Nouson: Sono Kouzou to Hendou. Kokinshoin (Tokyo). 